\title{
Strategy to Promote Professional Reading in University Libraries
}

\author{
Yunxia Zhou ${ }^{1,2} \&$ Xiaozhu Zou ${ }^{1,2}$ \\ ${ }^{1}$ Institute of Scientific and Technical Information, Nanjing University of Aeronautics and Astronautics, Nanjing, \\ China \\ ${ }^{2}$ Library, Nanjing University of Aeronautics and Astronautics, Nanjing, China \\ Correspondence: Xiaozhu Zou, Institute of Scientific and Technical Information, Nanjing University of \\ Aeronautics and Astronautics, Nanjing, 210016, China. Tel: 86-25-8489-2958. E-mail: zxzlib@nuaa.edu.cn
}

Received: July 3, 2018

doi:10.5539/cis.v11n 3p95

\author{
Accepted: July 12, 2018 \\ Online Published: July 28, 2018 \\ URL: https://doi.org/10.5539/cis.v11n3p95
}

\begin{abstract}
Reading promotion in university libraries needs to consider the differences in reading behavior of different readers and adopt suitable reading promotion strategies. Here, we first review the current situation of professional reading promotion and distinguish the demand characteristics of different types of readers. Then we conduct personal interviews with graduate students in Nanjing University of Aeronautics and Astronautics, and results demonstrate that the demands of graduate students for information on professional reading promotion and reading professional books and literatures become their indispensable demands in reading. Therefore, the visible display strategy to professional reading promotion is suggested for university libraries. Finally, taking an example of the reading promotion for zero-borro wing professional books, it is proved that the proposed strategy can increase the proportion of borrowed books and promote professional reading. In summary, we use tangible display strategy as theoretical basis and testify the proposed strategy for professional reading promotion: 1) a special cabinet displaying relevant professional books, 2) resources and charts, 3) placing bookshelves of stereoscopic models, and 4) designing and distributing a reading broch ure.
\end{abstract}

Keywor ds: professional reading promotion, visible display, university library

\section{Introduction}

The main purpose of the reading promotion in colleges and universities is to promote professional reading in university libraries. Through the investigation of the reading promotion in university libraries at home and abroad, Yang, Chen, \& Xie (2015) pointed out that the reading promotion and the popularization of the professional reading in libraries is necessary to promote the core values of a library. Zhang (2017) suggested that the information literacy course of current college students main ly adopted the traditional teacher-centered model; the teaching content was disjointed with the actual needs of the students, there was only one teaching method, and the school support was insufficient. A library is the repository of the information and knowledge of colleges and universities; and the most appropriate place to pro mote professional reading, which benefits the university in the long run. The promotion of professional reading is of great significance to colleges and universities for the following reasons: (1) the readers in universities have different learning goals and scientific research tasks. (2) the university readers, especially the students, have varying periods of unfamiliarity with the use of the university library. The university library can help readers to become familiar with its use as soon as possible. By analyzing the needs of different readers, this paper proposes the application of visible display strategy for professional reading promotion to promote professional reading promotion research.

\section{Advances in Professional Reading Promotion}

\subsection{Professional reading promotion in University Libraries in China}

\subsubsection{Concept of Professional Reading Promotion}

Professional reading promotion refers to the reading promotion by librarians in order to promote professional reading among teachers and students. It is obviously different from the popularization of public reading. Embedded subject services are combined with it (Liu, 2016). Liu (2011) believed that university libraries should integrate the promotion of professional reading with general reading promotion, and gradually expanded and improved the students' professional read ing scope and ability. Liu (2014) believed that the reading promotion of 
college libraries mostly stayed at the shallow level of reading, and the professional learning ability of students and scientific research needs of teachers urged libraries to carry out a more appropriate professional reading promotion. Zhang (2017) pointed out that university libraries could actively cooperate with the department level teaching units to optimize subject reading through the combination of professional reading and professional education.

\subsubsection{Promoting Professional Reading}

Yang Li et al. (2015), taking the library of Shanghai Jiao Tong University as an example, constructed a professional reading promotion model with triple-element interaction. It suggested that the development of professional reading promotion should follow the advanced service concept, activate service, establish cooperation mechanism, and carry out positive propaganda and marketing. The methods of professional reading promotion in university libraries had been investigated and it is suggested that the profe ssional classics bibliography used for promotion can be created by integrating the recommendations of domestic and international experts, professors in campus, and mentors / student pairs. Professional books should be put together in an orderly manner. The guided reading of the professional classics can be carried out by regularly inviting professional teachers in school to make up for the lack of professional knowledge of librarians. In addition, the dissemination of professional classics can be aided by new media and active interaction with readers. By inviting the readers in the school, the professional teachers, and so forth, professional reading was conducted via discussions and lectures. Moreover, it was suggested that the promotion of professional reading should be in accordance with the disciplines taught at universities and the ideas of self-development, and the school should create a good professional reading environ ment for the students. In recent years, little research has been reported on professional reading promotion in China; however, it can be seen that the promotion of professional reading is necessary to promote reading and popularize university libraries.

\subsection{Professional Reading Promotion in University Libraries of other Countries}

The earliest work regard ing reading promotion in university libraries can be traced back to the 1930s. A course related to reading promotion was taught by Professor Edwin Osgood Grover in the United States. Professional reading promotion by international university libraries pays more attention to the role of service. They provide efficient service to student readers to promote professional reading. For instance, the Nanyang Technology University Library in Singapore has established Subject Rooms and Subject Library Blogs to guide readers' in-depth reading of professional literature; the University of Michigan library prepares a book corner to exhibit professional books and journals recommended by faculties (Macadam, 1995). Based on students' feedback, the University of Cincinnati library provided appropriate in formation retrieval service for professional reading needs (Tenofsky, 2009). Through the survey, it is found that the promotion of professional reading in university libraries requires a positive communication and cooperation mechanism among all the departments, as well as outside the campus. Professional reading promotion should also attach importance to the role of basic services and should be continuous. Furthermore, the promotion of professional reading should focus on inculcating professionalism in librarians, the provision of a platform to optimize and innovate library services for readers, introducing state-of-the-art equipment, and providing all readers with regularly updated digital online content (Peters, 2009). However, reading promotion generally does not distinguish between readers. Therefore, adequate attention needs to be paid to the differences in needs of different readers. Besides, the status of literature in our society indicates that there has not been much research on professional reading promotion in university libraries.

\section{Objects of Professional Reading Promotion}

\subsection{Reading Demands of College Students at Different Learning Stages}

For college students, acquiring knowledge and relevant skills is the main task. They have higher reading needs, thus being the key objects in the reading promotion of college. Enabling college students to acquire more valuable professional knowledge in limited time will provide them with a good foundation for their future work. According to the learning characteristics of college students, the students' university years can be divided into several stages. The author, in view of the requirements and the familiarity with their library / libraries, interviewed some randomly-selected college students separately, and summed up answers in Table 1.

Table 1. Analysis of students' reading demand characteristics at different stages of learning

\begin{tabular}{ll}
\hline Learning stage & Characteristic of demand \\
\hline Freshmen & Without learning pressure, leisure, and with general reading \\
\cline { 2 - 2 }
\end{tabular}


as their focus, they are not very familiar with the library / libraries.

Under the pressure of study and examines, the knowledge

Sophomore \& Junior

Senior

Dissertation proposal

Diss ertation preparation acquisition regarding majors to get grades becomes the key purpose; and they are familiar with the library / libraries.

Driven by the postgraduate entrance examination, thesis writing, and employment choice, the demand for professional books and social science books is high among them; and they are familiar with the library / libraries.

The students need to know the background of the topic to conduct research, consult foreign books and related documents, learn to write articles, and be familiar with the library / libraries.

While conducting research, the students need to refer to specific books with more details; and they are familiar with the information relating to the library / libraries.

This paper selects undergraduate freshmen and graduate students as the object of reading promotion, and explores the professional reading strategies in university libraries. University libraries should provide professional reading promotion services to students according to their reading demands in different learning stages of their university life. There are certain professional limitations to breadth and depth of reading among the staff of university libraries. Therefore, the promotion of professional reading needs an active support from the graduate tutors, as well as professional and technical personnel of various colleges.

\subsection{Professional Reading Promotion with Service Marketing Strategies}

\subsubsection{Analysis on Demands of Professional Reading Via Personal Interview}

To intuitively demonstrate the demands of graduate students for information on professional reading promotion, we conducted personal interv iews with graduate students in Nanjing University of Aeronautics and Astronautics (NUAA). NUAA is a national multi-discip linary university, featuring aeronautics, aviation and aerospace science, which is directly governed by the Ministry of Industry and Information Technology, China. The respondents of our interview were limited to the graduate students in science and engineering. For our respondents, finishing the supervisors' scientific projects and preparing their dissertations are two major tasks during college. Reading professional books and literatures beco me their indispensable demands in reading. Since professional books and journals of different disciplines have different features, lib rarians should diversify service marketing strategies for graduate students in different disciplines when they begin to plan professional reading promotion.

Here, we list the interview results of 10 graduate students in the Department of Man-Machine and Environmental Engineering, NUAA, in Table 2.

Table 2. Personal interview results of graduate students in the Department of Man-Machine and Environmental Engineering

\begin{tabular}{lllllll}
\hline No. & $\begin{array}{l}\text { Frequently-read } \\
\text { professional books }\end{array}$ & $\begin{array}{l}\text { Approach to search } \\
\text { references }\end{array}$ & $\begin{array}{l}\text { Obstacle in research } \\
\text { and possible solutions }\end{array}$ & $\begin{array}{l}\text { Expectation on library } \\
\text { services }\end{array}$ \\
\hline 1 & Hydrodyna-mics, & CNKI search engine & Main obstacle: To & More & databases \\
Upper-level & basic gas dynamics, & for Chinese literatures, understand relevant & suggestion based on \\
graduate & FORTRAN & and Google search theories, & and & previous book records, \\
student & complete self-study & engine for English & read/write project & recommendation of \\
\cline { 2 - 6 }
\end{tabular}




\begin{tabular}{|c|c|c|c|c|}
\hline & $\begin{array}{l}\text { manual, theory and } \\
\text { application of } \\
\text { turbulent large } \\
\text { vortex numerical } \\
\text { simulation. }\end{array}$ & $\begin{array}{l}\text { literatures. First find } \\
\text { the relevant reviews } \\
\text { and doctoral } \\
\text { diss ertations, followed } \\
\text { with related literatures }\end{array}$ & $\begin{array}{l}\text { Solution: read papers } \\
\text { and books, ask } \\
\text { mentors, and discuss } \\
\text { with classmates. }\end{array}$ & $\begin{array}{l}\text { new books in related } \\
\text { fields }\end{array}$ \\
\hline $\begin{array}{l}2 \\
\text { Upper-level } \\
\text { graduate } \\
\text { student }\end{array}$ & $\begin{array}{l}\text { Simulation software } \\
\text { tutorials, numerical } \\
\text { calculation methods } \\
\text { related books. }\end{array}$ & $\begin{array}{l}\text { With Baidu Xueshu } \\
\text { search engine, go to } \\
\text { school library if need } \\
\text { download permission. } \\
\text { Search directly in the } \\
\text { library catalog with } \\
\text { determined journal } \\
\text { information (e.g. } \\
\text { AIAA). }\end{array}$ & $\begin{array}{l}\text { Main obstacle: how to } \\
\text { use the software } \\
\text { Solution: Baidu search } \\
\text { engine, literatures and } \\
\text { books with } \\
\text { professional } \\
\text { knowledge }\end{array}$ & $\begin{array}{l}\text { The scope of journals } \\
\text { should be broadened } \\
\text { with downloading } \\
\text { authorization. }\end{array}$ \\
\hline $\begin{array}{l}3 \\
\text { Upper-level } \\
\text { graduate } \\
\text { student }\end{array}$ & $\begin{array}{l}\text { Computational fluid } \\
\text { dynamics, finite } \\
\text { element method, } \\
\text { experimental design } \\
\text { and data processing. }\end{array}$ & $\begin{array}{l}\text { Enter the library to } \\
\text { find paper resources } \\
\text { and search for } \\
\text { electronic documents } \\
\text { through the library's } \\
\text { online database. }\end{array}$ & $\begin{array}{l}\text { Main obstacle: the use } \\
\text { of software, the rapid } \\
\text { understanding of } \\
\text { numerical theory, and } \\
\text { the preparation of } \\
\text { calculation programs. } \\
\text { Solution: Read and } \\
\text { study theoretical books } \\
\text { and periodical } \\
\text { conference documents, } \\
\text { learn software use help } \\
\text { documentation. }\end{array}$ & $\begin{array}{l}\text { Document search, } \\
\text { scientific report. }\end{array}$ \\
\hline $\begin{array}{l}4 \\
\text { Beginning } \\
\text { graduate } \\
\text { student }\end{array}$ & $\begin{array}{l}\text { Books and } \\
\text { documents related } \\
\text { to majors and topics } \\
\text { are mainly doctoral } \\
\text { dissertations. }\end{array}$ & $\begin{array}{l}\text { Library bookshelves to } \\
\text { find qualified books } \\
\text { and find electronic } \\
\text { resources through the } \\
\text { library website. }\end{array}$ & $\begin{array}{l}\text { Main obstacle: } \\
\text { software operation. } \\
\text { Solution: search } \\
\text { engine, related forums, } \\
\text { Weibo and Baidu, } \\
\text { small woodworm } \\
\text { forum and so on. }\end{array}$ & $\begin{array}{l}\text { Optimize the literature } \\
\text { search engine to } \\
\text { sharpen it. }\end{array}$ \\
\hline $\begin{array}{l}5 \\
\text { Beginning } \\
\text { graduate } \\
\text { student }\end{array}$ & $\begin{array}{l}\text { Aviation books, } \\
\text { topics related. }\end{array}$ & $\begin{array}{l}\text { CNKI search engine, } \\
\text { Baidu Xueshu search } \\
\text { engine }\end{array}$ & $\begin{array}{l}\text { Main obstacle: Some } \\
\text { technical difficulties in } \\
\text { scientific research. } \\
\text { Solution: Check } \\
\text { relevant documents } \\
\text { through the Internet, } \\
\text { visit forums, etc. }\end{array}$ & $\begin{array}{l}\text { Optimize search of } \\
\text { document keywords, } \\
\text { download electronic } \\
\text { books, or read online. }\end{array}$ \\
\hline $\begin{array}{l}6 \\
\text { Beginning } \\
\text { graduate } \\
\text { student }\end{array}$ & $\begin{array}{l}\text { Fluid mechanics, } \\
\text { fluent software, } \\
\text { aviation books. }\end{array}$ & $\begin{array}{l}\text { CNKI search engine, } \\
\text { Zhi Zhou search } \\
\text { engine }\end{array}$ & $\begin{array}{l}\text { Main } \\
\text { professional related } \\
\text { basic theory and model } \\
\text { data. } \\
\begin{array}{l}\text { Solution: } \\
\text { relevant } \\
\text { forums, etc. }\end{array}\end{array}$ & $\begin{array}{l}\text { Provide an electronic } \\
\text { magazine. }\end{array}$ \\
\hline $\begin{array}{l}7 \\
\text { Beginning } \\
\text { graduate } \\
\text { student }\end{array}$ & $\begin{array}{l}\text { Fluent software, } \\
\text { heat transfer and } \\
\text { other professional } \\
\text { related books. }\end{array}$ & $\begin{array}{lr}\text { CNKI, VIP } & \text { Chinese } \\
\text { Sci-Tech } & \text { Periodicals } \\
\text { database, } & \text { AIAA } \\
\text { database } & \end{array}$ & $\begin{array}{l}\text { Main obstacle: } \\
\text { Software use and } \\
\text { related theoretical } \\
\text { knowledge. } \\
\text { Solution: Find related } \\
\text { documents, consult } \\
\text { with Baidu and } \\
\text { professional forums, } \\
\text { etc. }\end{array}$ & $\begin{array}{l}\text { Expand the scope of } \\
\text { the literatures that can } \\
\text { be downloaded. }\end{array}$ \\
\hline
\end{tabular}




\begin{tabular}{|c|c|c|c|c|}
\hline $\begin{array}{l}8 \\
\text { Beginning } \\
\text { graduate } \\
\text { student }\end{array}$ & software, & $\begin{array}{l}\text { Baidu Xueshu search } \\
\text { engine, CNKI search } \\
\text { engine }\end{array}$ & $\begin{array}{l}\text { Main obstacle: how to } \\
\text { use the software; } \\
\text { Solution: Literature } \\
\text { searching and } \\
\text { reviewing, brothers } \\
\text { and sisters in the } \\
\text { consulting group. }\end{array}$ & $\begin{array}{l}\text { Complete the contents } \\
\text { of the CDs in books. }\end{array}$ \\
\hline $\begin{array}{l}9 \\
\text { Upper-level } \\
\text { graduate } \\
\text { student }\end{array}$ & $\begin{array}{l}\text { Fluid mechanics } \\
\text { related books }\end{array}$ & $\begin{array}{l}\text { CNKI search engine } \\
\text { for Chinese literatures, } \\
\text { and Web of Science, } \\
\text { SciHub, AIAA } \\
\text { databases for English } \\
\text { literatures }\end{array}$ & $\begin{array}{l}\text { Main obstacle: how to } \\
\text { read the literature } \\
\text { efficiently and find } \\
\text { innovative ideas } \\
\begin{array}{l}\text { Solution: } \\
\text { supervisors }\end{array} \text { Ask } \\
\begin{array}{l}\text { discuss } \\
\text { classmates, or }\end{array} \\
\begin{array}{l}\text { online } \\
\text { ondith }\end{array} \\
\end{array}$ & $\begin{array}{l}\text { Video instructions for } \\
\text { all online tools }\end{array}$ \\
\hline $\begin{array}{l}10 \\
\text { Upper-level } \\
\text { graduate } \\
\text { student }\end{array}$ & Aviation books. & $\begin{array}{l}\text { Library database and } \\
\text { Internet }\end{array}$ & $\begin{array}{l}\text { Main obstacle: Some } \\
\text { technical problems } \\
\text { encountered in project. } \\
\text { Solution: Check out } \\
\text { relevant literatures and } \\
\text { forums. }\end{array}$ & More books to borrow. \\
\hline
\end{tabular}

\subsubsection{Professional Reading Demands and Library Services Strategies}

As can be seen in Table 2, the students in same majors read similar books. Beginning graduate students searched for references mainly through library bookshelves, CNKI search engine, Baidu search engine, etc., whilst upper-level graduate students explored more approaches, for instance, Chinese references by CNKI and Baidu and English references by library-based electronic databases. When facing obstacles in their research, they will tackle problems by: 1) using the library database to find references; 2) browsing professional forums and consulting QQ group friends; 3) contacting professors or higher-level graduate students. Their main expectation on library services focus on recommendation of more professional books, increase of electronic databases, and easy-found instructions of online tools. These interview results are representative. It is found that the library plays a vital role in the research activities of graduate students and provides services passively. Therefore, when the librarians develop marketing strategies for readers, they should take initiative and supply the readers with active services.

\section{Application of Tangible Display Strategy in Professional Reading Promotion in Libraries}

\subsection{Visible Display Strategy}

Visible display is one of the elements of the service marketing combination strategy, including the human and environment factors. A library is also a service organization, and the tangible display is an essential element of service (Tang, 2010). As a part of the library service, the books are displayed in the library, the special column holding books is displayed in a specific position, the guide for the reader is set up in the library, and the visible display strategy is effectively used via displaying new media content. The visible display strategy takes people and processes into account; and it can play an important role in the reading promotion. In view of the different types of readers, university libraries can use the strategy of visible display to promote professional reading.

\subsection{Professional Reading Promotion Strategy}

Since there is a lack of awareness about the use of library among undergraduate and graduate students, professional reading promotion can play a positive role in helping these students. This can be realized through the following: 1) The analysis of the book borrowing data and the professional reading bibliography designated by relevant teachers, setting up a special cab inet for professional books in the library, and displaying specialized books, such as books in Chinese, books in foreign languages, new books, and zero-borrowing books. Intuitive display of special counters enables freshmen to understand and learn on their own. 2) Displaying the floor plan and resource presentation card at the entrance of each floor. Since the library's book resources are distributed over different floors, after display, the readers become aware of the floor resources, and the frequency that they ask the staff for help to find the needed books has been reduced by $80 \%$. 3) Designing stereoscopic library 
shelves and labeling the resource classification number to increase readers' awareness about the library as well as stimulate their interest. 4) During Freshmen training, effective physical presentation can achieve twice the result with half the effort. Librarians can draw up a library brochure during professional reading promotion. The brochure may contain the contents as shown in Figure 1.

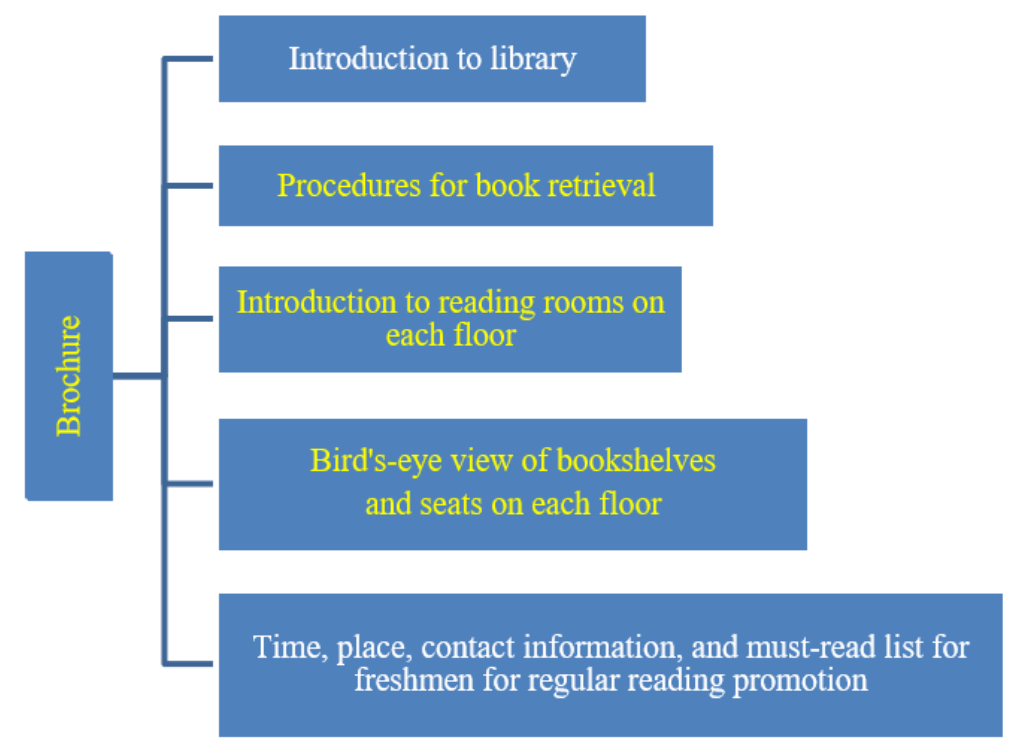

Figure 1. Contents of library brochure

With the help of this brochure, new readers can quickly familiarize themselves with the contents of the library, the distribution of resources on the floor, and the spatial distribution of the library, and then facilitate the process of borrowing books.

\section{Demonstration: Taking Nanjing Uni versity of Aeronautics \& Astronautics Library of the Ming Imperial Palace as an Example}

\subsection{Displaying Processing of Zero-Borrowing Professional Books}

Borrowing rate refers to the ratio of the number of books borrowed to the volume of books. Zero-borrowing means the ratio is zero. According to the service marketing strategy, the Ming Imperial Palace Museum of NUAA selected a part of zero-borrowing professional books from the library to be displayed for nearly three years. It was displayed on the first floor of the hall, and recorded as a two-week loan in the records. After displaying the zero-borrowing books, the number displayed was changed. We recorded the data in Table 3 .

Table 3. Zero-borrowing professionalbooks exhibit two-week data records

\begin{tabular}{rcccc}
\hline & Exhibited & Stay & Take away & loan \\
\hline $1^{\text {st }}$ week & 198 & 127 & 71 & 54 \\
$2^{\text {nd }}$ week & 170 & 89 & 81 & 46 \\
\hline
\end{tabular}

Note. "Exhibited" meant the number of the zero-borrowing professional books drawn from the library. "Stay" indicated the number of books left on the display shelf a week later. "Take away" indicated the number of books that readers took away from the shelf a week later. "Loan" indicated that the book "taken away" from the library management system was borrowed, or the books were out. The lending data shown after the exhibition verified the role of visible display strategy in professional reading promotion.

\subsection{Strategy Used in Zero-Borrowing Professional Reading Promotion}

The visible display strategy is applied here. Two weeks of display data demonstrates that borrowing rates for books have changed from zero to $27 \%$ (These books are already seen as due since there is no past data; however, recommending zero-borrowing books continues). Visible display strategies include setting up independent bookshelves in the areas that are often frequented by people, exhibiting books with zero-borrowing rate, and 
setting up elaborate presentation cards beside the bookshelves, etc. The title on the spine is clear at a glance, the first-floor hall is ventilated throughout four seasons, and the temperature is optimum. Various factors that concern different readers while browsing in this bookshelf are fully considered.

\section{Conclusions}

This paper first analyzes the current status of professional reading promotion, distinguishes the needs of different types of readers, and applies the visible display strategy to the promotion of professional reading in libraries. It takes tangible display strategy as its theoretical basis and proposes the strategy of professional reading promotion: 1) special cabinets displaying relevant professional books, 2) posting resources and charts, 3) placing stereoscopic models of bookshelves, and 4) making a library brochure. Finally, through the example of zero-borrowing professional book reading promotion, it is proved that the strategy proposed in this paper can promote book reading satisfyingly. The professional reading promotion in university libraries needs to consider the differences in readers' reading behaviors and adopt a suitable reading promotion strategy.

\section{References}

Liu, C. E. (2014). Some Misunderstanding of Reading Promotion Activities in Domestic Academic Libraries. Library, 3, 111-112. https://doi.org/10.3969/j.issn.1002-1558.2014.03.030

Liu, L. (2016). Discussion on the reading promotion of the university library. Library Research, 46(3), 88-91. https://doi.org/10.3969/j.issn.2095-5197.2016.03.023

Liu, Y. L. (2011). Research on the classical reading guide in academic library. Library Work in Colleges \& Universities, 1, 81-83. https://doi.org/10.3969/j.issn.1003-7845.2011.01.024

Macadam B. (1995). Sustaining the culture of the book: The role of enrich ment reading and critical thinking in the undergraduate curriculum. Library Trends, 44(2), 237-263.

Peters T. (2009). The Future of Reading. Library Journal, 134(18), 18-22.

Tang, H. (2010). Strengthen physical evidence and promote library services' quality. Library Tribune, 30(01), 114-116.

Tenofsky, D. (2005). Teaching to the whole student: Building best practices for collaboration between libraries and student services. Research Strategies, 20(4), 284-299. https://doi.org/10.1016/j.resstr.2006.12.023

Yang, L., Chen, Y. H., \& Xie, R. (2015). Reading promotion services in university libraries. Library Journal, 34(12), 29-37. https://doi.org/10.13663/j.cnki.lj.2015.12.005

Zhang, J. H. (2017). A study of the strategy of improving college students' information literacy in the learning environment. Library Journal,36(12),75-79. https://doi.org/10.13663/j.cnki.lj. 2017.12.010

Zhang, X. (2017). Research on the Reading Pro motion and Optimization Paths of University Libraries under the Background of Industrial Culture. Library Science Research \& Work, 6, 71-75. https://doi.org/10.3969/j.issn.2096-2363.2017.06.017

\section{Copyrights}

Copyright for this article is retained by the author(s), with first publication rights granted to the journal.

This is an open-access article distributed under the terms and conditions of the Creative Commons Attribution license (http://creativecommons.org/licenses/by/4.0/). 